\title{
The Formation of Responsive Regional Regulations in Supporting Regional Autonomy in Pekanbaru City
}

\author{
Amri Hakim ${ }^{1}$ and Hizra Marisa ${ }^{3}$ \\ ${ }^{1,2}$ Universitas Abdurrab, Pekanbaru, Indonesia \\ amri.hakim@univrab.ac.id
}

\begin{abstract}
This article aims to produce regional laws that are responsive in supporting the implementation of regional autonomy so that the implementation of regional autonomy does not create new problems that can hinder or damage economic development and growth in a region. In this study, several legal approaches used include the main approach of Law number 32 of 2004 concerning regional autonomy and Law number 12 of 2011 concerning the law on the establishment of legislation. Another approach approached in one case is a historical approach, a comparative approach, and a conceptual approach. Results illuminate how the drafting of Perda constitutes based on certain principals (i.e. clarity of objectives, appropriate institutional or organ formation, compatibility between types and material content) can accommodate local wisdom for the community and avoid potentially problematic regulations in the regions.
\end{abstract}

Keywords: Regional Regulation; Regional Autonomy; Law

\section{Introduction}

The local or regional government in Indonesia, colloquially known as perda, is a strategic instrument that acts as a means of achieving the goals of decentralization. The authority to establish a regional regulation is one form of regional independence in regulating regional household affairs or regional government affairs (Talitha, Firman, \& Hudalah, 2020). From the perspective of political empowerment, the goal of decentralization can be seen from two sides, namely the local government and the central government. The purpose of decentralization in terms of regional government is to realize political equality, local accountability, and local responsiveness.

The existence of regional regulations in the 1945 Constitution before the amendment was indeed unknown, so the regional regulations were marginalized in the composition of the Indonesian laws and regulations (Tegnan, 2018). After the 1945 Constitution was amended, the existence of the Regional Regulation was constitutionally confirmed as stipulated in Article 18 paragraph (6) which reads in full;
Regional Government has the right to stipulate regional regulations and other regulations to carry out autonomy and assistance tasks. As the main basis of the authority of the DPR in proposing the Draft Law contained in the provisions of Article 20 paragraph (1), states that the House of Representatives holds the power to form a law (Sugiharto, 2020). Furthermore, it is reiterated that Article 21 states that members of the People's Legislative Assembly have the right to submit proposals for a bill. The birth of Law Number 12 of 2011 has made a very important basis in making legislation because it will show: The necessity of the authority of the legislators; the necessity of conformity with the form or type of laws and regulations with the material that is regulated, especially if the higher level or equivalent rules are ordered; must follow certain procedures; the necessity does not conflict with the higher-level legislation.

Law Number 12 of 2011 concerning the Formation of Regulations and Regulations, Article 39 states that the planning for the compilation of regency/city regional regulations is carried out in 
regency/city Prolegda. In this article, the community believes that the DPRD has an important role in drafting regional regulations. The Regional Legislation Program (Prolegda) as referred to earlier was prepared jointly by the DPRD and the Regional Government which was determined for 1 (one) year (Simatupang, 2019). Prolegda is an instrument of program planning for the formation of Regional Regulations which are planned and systematically arranged according to the priority scale specified. Regional regulations are instruments in the implementation of regional autonomy to determine the direction and policies of regional development and supporting facilities. However, in the development of the practice of regional autonomy, the problem after an issue arose regarding the enactment and implementation of this Perda, until then the Central Government (Pempro) was overwhelmed to carry out supervision until its cancellation.

Regional regulations are unique regional products because they are produced from a process that is dominated by local political interests. Since regional autonomy is rolling, thousands of regional laws and levies have appeared which are currently burdening investors. This regulation is considered to cause high-cost economic problems that have an impact on economic growth, both local and national. So, many local governments take advantage of opportunities to increase PAD through Regional Regulations. The birth of a Regional Regulation (Perda) must contain a regulation that can be adhered to by the community, and to support this it is very necessary to understand the desires and social conditions of the community so that it can be applied over a long period. Therefore, philosophical considerations must be clear where the community will be taken. To achieve a responsive Regional Regulation in supporting Regional Autonomy, designers should pay attention to the principles of the formation of a Regional Regulation as a reference frame such as clarity of objectives, appropriate institutional or organ formation, compatibility between types and material content.

\section{Method}

Regional regulations are formed based on the principle of formation of legislation which includes: clarity of purpose; appropriate institutions or forming organs; compatibility between type and material content; can be implemented; usefulness and usefulness; clarity of formulation; and openness.

Perda is all regulations made by the local government to implement other regulations that are higher in rank. Therefore, the Regional Regulations generally include, among others: Matters relating to regional households and matters relating to regional government organizations, Matters relating to duties and assistance (Mendebewindl) thus the Regional Regulation is a legal product of the regional government in the context of implementing regional autonomy, namely exercising the right and authority to regulate and manage their domestic affairs as well as the Regional Regulation constitutes legality to support the Provincial Government as an autonomous region (Wilian, 2020). Furthermore, the contents of the regional regulation can come from several sides, including comes from the delegation of the Act due to regional initiatives, translation of adat, translation of religion.

Taking into account the content of the Perda, it can be stated that if the drafting of the Perda constitutes or implements these things, it is expected that the Perda can give meaning to the community, especially in accommodating local wisdom. Making legislation by the above-mentioned principles will avoid any problematic regional regulations.

\section{Results and Discussion}

Regional Regulation Planning Based on Article 10 Regulation of the Minister of 
Home Affairs Number 80 the Year 2015 Concerning the Establishment of Regional Legal Products, the Planning for the Provincial Regional Regulation covers the following activities: (a) Formulation of Regional Regulation Formation Programs; (b) Planning for the compilation of the Open Cumulative Regional Regulation; and (c) Planning for drafting Regional Regulation Outside the Regional Regulation Formation Program. Regional Regulation Planning is the initial stage in the formation of Regional Regulations. Planning for the preparation of Provincial Regulations is carried out in the Provincial Regulations Formation Program that contains the Provincial Regulations Formation Program with the title: Provincial Regulations Draft, regulated material, and linkages with other Regulations. Related to the stipulation of the Regional Regulation Formation Program in a decision of the Regional House of Representatives, it has been regulated in the Minister of Domestic Affairs Regulation No. 80 of 2015 concerning the Establishment of Regional Legal Products. Article 15 Paragraph (4) of the Regulation of the Minister of Home Affairs states clearly that "Preparation and stipulation of provincial Propemperda are carried out every year before the stipulation of regional regulation on provincial APBD" This means that the determination of the Program for the Establishment of Regional Regulations of Riau Province must be carried out before the stipulation of Regional Regulation on Regional Revenue and Expenditure Budget of Riau Province.

Formulation of Regional Regulations Formulation of Regional Regulations was carried out by the Regional Regulatory Formation Board of Riau Province after the Formation of Regional Regulations Formation Program was set for one year, by first conducting Harmonization, Rounding, and Consolidation of Regional Regulation Draft proposed by proposers, both from Provincial DPRD Riau (Members, Commissions and/or Joint Commissions, and other DPRD Completeness Devices), as well as from the Regional Government of Riau Province. Harmonization, Rounding, and Consolidation of the Conception was carried out before the Draft Regional Regulation was submitted to the Chairperson of the Regional House of Representatives (Jamallullail, 2020). Harmonization, Rounding, and Consolidation Mechanisms The draft of the Regional Regulation is carried out by carrying out consultations with the Directorate General of Regional Legal Products of the Ministry of Home Affairs of the Republic of Indonesia. At the time of the implementation of the Consultation, the Regional Regulation Draft that initially did not have an Academic Script or the Academic Script was not yet perfect, so at the time of the Consultation, the Regional Regulation Draft was accompanied by the Academic Script (Alimudin \& Suparman, 2018). The results of the study of the Regional Regulatory Formation Board of the Riau Provincial Representative Council based on the Regional Regulatory Formation Board Meeting on July 26, 2015, addressed to the Chairperson of the Riau Regional Representative Council with Number 58/ND/BPPD/VII/2015 states that the Draft Regional Regulation Regarding Ulayat Land and Its Utilization Can Be Continued.

Discussion on Regional Regulations Discussion on the Draft Regulation of the Riau Province is carried out by the Riau Regional Representative Council which in its implementation is carried out by a Special Committee with the relevant Regional Apparatus, and by involving the Regional Office of the Ministry of Law and Human Rights of the Riau Province which is carried out through the stages of discussion. The stages of the discussion were carried out in a Special Committee Meeting which was then followed by a Plenary Session of Ratification of the Draft Regional Regulation. In the discussion of the Draft Regional Regulation on Ulayat 
Land and its Utilization, starting with the Hearing or Hearing Meeting with the Riau Malay Customary Institution and other related institutions, which was held on November 12, 2015, at the Riau Malay Customary Institution Building, Jl. Diponegoro, Pekanbaru.

However, the Minutes of Meeting and Conclusions, and Recommendations from the Meeting were not written in written form in the Final Report of the Special Committee, so that the author did not obtain more in-depth information about the results of the meeting, both on the actual issue, inventory of the existence of the customary and Land Law communities. Ulayat, as well as the substance of the Ranperda material. The next agenda or discussion on the Draft Regional Regulation on Ulayat Land and Utilization is Hearing with the Malay Regency/City Malay Customary Institutions in Riau Province, on November 16, 2015. However, the Minutes of Meeting and Conclusions of the Hearing Meeting were also not listed in the Final Report Special Committee.

Furthermore, to deepen the substance to be regulated in the Regional Regulation Draft, and to obtain comparisons related to the existence and implementation of regulations governing the existence of indigenous and tribal peoples, the Special Committee will carry out a working visit to the Ministry of Agrarian Affairs and Spatial Planning, BPN RI on 12-14 November 2015, and Working Visit to Bali Province on 19-21 November 2015. Of the 2 (two) visits, the Minutes of Meeting and Conclusions of the Meeting were also not included in the Final Report of the Special Committee. Regarding public testing, it is usually carried out before the Regional Regulation is finalized, the purpose is to receive input, suggestions, and opinions and the urgency and substance of the material. Usually, it is carried out by the Special Committee while the Regional Regulation Draft Discussion is being carried out, even though it is based on the Provisions, the authority is in Regional Regulation
Formation Board, by calling on stakeholders during the public trial.

\section{Conclusion}

In the formation of regional regulations which must be in regional autonomy, and carried out by existing mechanisms in Law Number 12 of 2011 concerning Formation of Legislation. If there are still practices found in problematic regional regulations, it is because in the formation of regional regulations in the context of regional autonomy there are still those who abuse their authority and overlap between government institutions and applicable regulations, both between higher rules and lower rules.

Another factor is also due to the interests of local elites who use regional autonomy as momentum to achieve their political interests by mobilizing the masses and developing regional sentiments (Ikhsan, Ghani, \& Ishak, 2017; Tilome et al., 2020), such as the slogan "Regional Putera" in regional elections and the occurrence of a misunderstanding of the application of Political Law so that it is used legal means in the world of politics in pouring the material content of the law.

To support Regional Autonomy, the concept of a Regional Regulation used is where the process of making it must pay attention to and start from the planning, discussion, preparation techniques, formulation, discussion, endorsement, enactment, and dissemination. In preparing the discussion and ratification of the draft regional regulation into a regional regulation, it must be guided by statutory regulations. Regional regulations will be more operational if in their formation they are not bound by the principle of legality, which is meant in the provisions of Article 136 to 147 of Law Number 32 of 2004, but still needs to be supplemented with the results of an in-depth examination of the subjects and legal objects to be regulated, as well as must begin with the formation of an academic paper and must be socialized to the public to get feedback. The content of 
the Perda should be by the legal needs of the community and receive community aspirations or input from the community so that it is expected to be by the spirit of regional autonomy.

\section{Acknowledgement}

This research was supported by Universitas Abdurrab. The authors thank their colleagues from the institution who provided insight and expertise that greatly assisted the research.

\section{References}

Alimudin, B., \& Suparman, E. (2018). Optimalization of the Role of The Dprd (Regional House of Representative) in the Preparation of Regional Regulations. In The 3rd International Conference and Call for Paper (Vol. 1, No. 1).

Ikhsan, M. F., Ghani, A. B. A., \& Ishak, M. S. (2017). The Dynamics of the Chinese Business Practice and the Local Elites Behavior: The Legacy of Pseudo-Capitalism in Indonesia's Local Development. Journal of Governance and Development Vol, 13(2).

Jamallullail, I. (2020). Politics of Law in the Establishment of a National Regulatory Body: A New Direction for Legal Reform. Journal of Law and Legal Reform, 1(4), 681-690.
Simatupang, T. H. (2019). Mendudukkan Konsep Executive Review Dalam Sistem Hukum Ketatanegaraan Indonesia. Jurnal Penelitian Hukum De Jure, 19(2), 217-229.

Sugiharto, I. (2020). Mechanism of the President and DPR Relationship in Indonesian State Government Law According to 1945 Basic Laws in Historical Perspective After Amendment. ENDLESS: International Journal of Future Studies, 3(1), 15-25.

Talitha, T., Firman, T., \& Hudalah, D. (2020). Welcoming two decades of decentralization in Indonesia: a regional development perspective. Territory, Politics, Governance, 8(5), 690-708.

Tegnan, H. (2018). Analysis of the Indonesian Presidential System Based on the 1945 Constitution of the Republic of Indonesia. Journal of Legal, Ethical and Regulatory Issues, 21(3), 1-8.

Tilome, A. A., Agustang, A., Jasruddin, M. S., \& Asrifan, A. (2020). Social Exchange of Political Elites in the Regional Leader Election of Gorontalo Province, Indonesia. Solid State Technology, 63(5), 521-531.

Wilian, A. F. (2020). Peran Kanwil Kemenkumham Dalam Harmonisasi Ranperda perspektif Siyasah Dusturiyah. Al-Balad: Journal of Constitutional Law, 2(1). 